\title{
Salmonid alphavirus (SAV)
}

\author{
Izabela Deperasińska $^{1}$, Patrycja Schulz ${ }^{2}$, Andrzej K. Siwicki ${ }^{1}$ \\ ${ }^{1}$ Department of Fish Pathology and Immunology, Inland Fisheries Institute, 10-719 Olsztyn, Poland \\ ${ }^{2}$ Department of Microbiology and Clinical Immunology, Faculty of Veterinary Medicine, \\ University of Warmia and Mazury in Olsztyn, 10-719 Olsztyn, Poland \\ patrycja.schulz@uwm.edu.pl
}

Received: November 9, $2017 \quad$ Accepted: March 15, 2018

\begin{abstract}
Salmonid alphavirus (SAV), genus Alphavirus, family Togaviridae, is a single-stranded RNA virus affecting Atlantic salmon (Salmo salar) and rainbow trout (Oncorhynchus mykiss). It is known to be responsible for pancreas disease (PD) and sleeping disease (SD) which are increasing problems, causing high fish mortality and economic losses in the European aquaculture industry. Pancreas disease was first described in Atlantic salmon in Scotland in 1976 and a similar disease caused by the closely related sleeping disease virus was first described in rainbow trout in France. There have also been reports of salmonid alphavirus infections from other European countries, including Ireland, England, Norway, Germany, Italy, and Spain. Salmonid alphaviruses have been classified into six subtypes (SAV1-6). SAV1 and SAV4-6 cause pancreas disease in Atlantic salmon in Ireland or Scotland, SAV2 is the causative agent of sleeping disease in rainbow trout, and SAV3 has been detected in Atlantic salmon in Norway. The aim of this paper was to summarise current knowledge of infections caused by salmonid alphavirus and diagnostic methods including the newest techniques, and to briefly describe prevention from SAV infections by vaccination.
\end{abstract}

Keywords: Atlantic salmon, rainbow trout, salmonid alphavirus, pancreas disease, sleeping disease.

\section{Introduction}

Salmonid alphavirus (SAV) is an enveloped, singlestranded, positive-sense RNA virus with a $\sim 12 \mathrm{~kb}$ genome, belonging to the family Togaviridae, genus Alphavirus. It is known to be a serious pathogen for Atlantic salmon (Salmo salar) and rainbow trout (Oncorhynchus mykiss) in Europe. SAV is responsible for pancreas disease (PD) affecting Atlantic salmon, first reported in Scotland in 1976 (26). A similar disease, termed "sleeping disease" (SD) and affecting rainbow trout has been described and reported in France (6). A comparative histopathological study (6) suggested that both diseases were caused by a similar or identical agent. Later, it was shown that both diseases are caused by closely related members of the same species. Weston et al. (38) conducted analyses of the complete genomes of a salmonid pancreas disease virus (SPDV) and sleeping disease virus (SDV). These genomes were sequenced and compared, demonstrating that both viruses are very similar at nucleotide and amino acid sequence levels. Recently, SAV has also been isolated from wild-caught non-salmonid marine fish species, namely flatfish spp. in Scotland and Ireland (24). Both $\mathrm{PD}$ and $\mathrm{SD}$ are becoming more serious problems with rising economic importance in the European aquaculture industry (21). SAV infections were listed by the OIE in $2014(19,21)$ and as a result, countries that are SAV-free are allowed to refuse to import salmon products from areas that have not been declared SAV-free, regardless of existing free trade agreements. Presumably, this may cause some additional economic losses. However, there is no scientific information on the level of risk related to the export of SAV-infected whole or filleted salmon (fresh or frozen) to countries or areas that are free from SAV (21).

\section{SAV subtypes}

The SAV genome is a single-stranded, positivesense RNA with two open reading frames (ORFs). It encodes eight proteins: four structural capsid glycoproteins (E1, E2, E3, and $6 \mathrm{~K}$ ) by the 3 ' end and 
four nonstructural proteins (nsP1-4) by the $5^{\prime}$ end (38). Protein E2 has an important function in receptor binding to the host cell, mediating the internalisation of the virus and playing a major role in the final envelope formation and in the budding of new viruses (10). Moreover, most neutralising epitopes are present on the E2 glycoprotein, while E1 protein contains more conserved, cross-reactive epitopes (26). Six subtypes of salmonid alphavirus (SAV1-6) have been created (Table 1) based on the nucleic acid sequences of genes encoding E2 and nsP3. A study on the serological cross-reactivity between the different subtypes of SAV was conducted by Graham et al. (16). The results of that comparative cross-neutralisation study were consistent with the different subtype strains tested being serologically closely related members of the same viral species.

Salmonid alphavirus subtype 1 (SAV1) has been described as the causative agent of pancreas disease in Atlantic salmonids in Ireland and Scotland $(14,27)$. Sleeping disease in rainbow trout is known to be caused by the second subtype of SAV (SAV2). SD has been detected in France (6, 8), England and Scotland (11), and Germany (4). It has been also reported in Italy and Spain (13) and more recently in Poland (5) and Switzerland (30). SAV2 has been divided into two subgroups (Table 1) named freshwater variant (SAV2 FW) and marine variant (SAV2 MW). Infections with SAV2 FW cause sleeping disease in freshwater-reared rainbow trout in England, Scotland, and mainland European countries (21). The marine variant of SAV2 (SAV2 MW) is responsible for pancreas disease in seawater-reared Atlantic salmon. The third subtype of salmonid alphavirus (SAV3) has been isolated from farmed Atlantic salmon in Norway (17), hence it is also named Norwegian salmonid alphavirus (NSAV). SAV3 causes pancreas disease in Atlantic salmon and sea-reared rainbow trout. It has been shown that SAV3 has genomic organisation identical to that of SAV1 and SAV2 (26). To date, SAV3 has only been detected in Norway, where until 2010 no other subtypes were detected $(17,20)$. Subtypes 4-6 of SAV (SAV4-6) have been detected in Scotland and Ireland in connection with PD outbreaks (10) and detected there along with SAV1 (14).

\section{Virus transmission}

The main transmission way of salmonid alphavirus appears to be horizontal and via water contact. This has been supported both by experimental trials $(27,35)$ and field observations. Kongtorp et al. (23) investigated the possibility for vertical transmission of SAV subtype 3. The results demonstrated that SAV3 was not readily transmitted vertically from parents to offspring. It is concluded that if it happens at all, vertical transmission is of minor importance in the spread of SAV 3. There are some studies suggesting that SAV transmission between farms is caused by passive drift in the water currents (33, 36). Transport of fish may probably increase the risk of spreading SAV across longer distances, even outside Europe.

\section{Pancreas disease}

Pancreas disease is an infectious disease affecting specifically Atlantic salmon and it was first detected in Scotland in the 1970s. Later, there were reports of the disease in farmed Atlantic salmon from Ireland and Norway. There were no reports of PD outbreaks outside Europe but for one exception when the disease was described in North America (without detection a virus) (21).

SAV1 can be isolated in all regions of Ireland, which makes it the dominant SAV subtype in this country. However, SAV4 can also be found in northwest Ireland. In Norway, more subclinical cases of PD are caused by marine SAV2 infections than by SAV3 (21). There is also a study suggesting that about a third of populations infected by SAV may not develop clinical PD (1).

PD usually occurs in salmon smolts during the first year at sea but recently there have been more reports showing that other year classes of Atlantic salmon are also susceptible. Outbreaks are common between late July and early September (26). Clinical signs associated with PD include sudden inappetence, lethargy and an increased number of faecal casts in the cages, increased mortality and ill-thrift $(25,26)$. The histopathological changes in fish affected by PD and SD primarily occur in the pancreas, heart, and skeletal muscles. For many years, the descriptions of PD from Scotland and Ireland (reviewed by McLoughlin et al. (25)) were used in detecting the disease. However, the pathological findings in the Norwegian cases were different to some extent from those observed in Scotland and Ireland. Therefore Taksdal et al. (34) conducted a study in which they described the clinical signs of PD and necropsy findings in farmed Atlantic salmon and rainbow trout in sea water in Norway. They compared their findings with reports of PD from Ireland and Scotland. A recent study has revealed important changes in the dermal bacterial microflora composition of Atlantic salmon in response to infection with SAV3 (29). The changes are characterised most prominently by the loss of Proteobacteria and may render the fish more susceptible to secondary infections by opportunistic bacterial pathogens present in the environment or within the host indigenous microbial reservoir.

\section{Sleeping disease}

Sleeping disease (SD) is an infectious disease similar to pancreas disease; however, it affects rainbow trout reared in fresh water. It was first observed in France (6) and the virus (SDV) was isolated a few years later (8). 
Table 1. Summary of salmon alphavirus (SAV) subtypes

\begin{tabular}{lllll}
\hline Virus subtype & Optional virus name & Disease & Species & Location \\
\hline SAV1 & Salmon pancreas disease virus & PD $^{1}$ & $\begin{array}{l}\text { Atlantic salmon (sea water) } \\
\text { Rainbow trout (fresh water }\end{array}$ & Ireland, Scotland \\
\hline SAV2 FW & Sleeping disease virus & SD $^{2}$ & $\begin{array}{l}\text { Rainbow trout (fresh water) } \\
\text { Atlantic salmon (sea water) }\end{array}$ & $\begin{array}{l}\text { France, England, Scotland, Germany, Italy, } \\
\text { Spain, Poland, Switzerland }\end{array}$ \\
\hline SAV2 MW & Salmon pancreas disease virus & PD & Atlantic salmon (sea water) & Norway, Scotland \\
\hline SAV3 & Norwegian salmon alphavirus & PD & $\begin{array}{l}\text { Atlantic salmon (sea water) } \\
\text { Rainbow trout (fresh water) }\end{array}$ & Norway \\
\hline SAV4 & Salmon pancreas disease virus & PD & Atlantic salmon (sea water) & Ireland, Scotland \\
\hline SAV5 & Salmon pancreas disease virus & PD & Atlantic salmon (sea water) & Scotland \\
\hline SAV6 & Salmon pancreas disease virus & PD & Atlantic salmon (sea water) & Ireland \\
\hline
\end{tabular}

${ }^{1} \mathrm{PD}$ - pancreas disease, ${ }^{2} \mathrm{SD}$ - sleeping disease

The causative agents of SD and PD are closely related members of the same species, generally known as salmonid alphavirus, which has been proven by complete genome sequencing (38). The causative agent of SD is the subtype 2 (SAV2) (37).

$\mathrm{SD}$ is an increasing problem not only in France but throughout Europe, causing higher mortality and growth retardation of fish. It is known to affect rainbow trout at all stages of production (26). SAV2 has been isolated in England and Scotland (11), in Italy and Spain (13), and in Germany (4). More recently, the first laboratory confirmation of SAV2 infection in Poland has been described (5), and the first outbreak of sleeping disease in Switzerland has been reported (30).

The characteristic sign of sleeping disease is the unusual behaviour of affected fish, manifested in their laying on their side on the bottom of the tank, hence the name "sleeping" disease. Extensive necrosis of skeletal red muscles is considered to be the cause of this behaviour. This chronic stage follows the development of characteristic sequential histological lesions of the exocrine pancreas and heart (6).

\section{Diagnostic methods}

Initially, the diagnosis of PD and SD was based on clinical signs combined with typical histopathological findings. Currently, a combination of histopathological examination, antibody detection, virus culture, and PCR technique is used. Detailed descriptions of SAV diagnostic methods are contained in the Manual of Diagnostic Tests for Aquatic Animals published by the OIE (19). The first successful isolation of SAV1 was described by Nelson et al. (27) and after that the first isolation of SAV2 was reported by Castric et al. (8). Later, it was shown that infectious salmonid alphavirus can be detected in serum samples from salmon and trout by a relatively simple procedure (22). The described method requires minimal sample preparation and antigenic characterisation studies can be performed with viruses after only one passage in cells. Between 2002 and 2007 over 200 viraemic salmon and trout sera were identified using this approach (26).

However, since methods based on antibody detection and virus isolation are time-consuming and have some limitations, one such being that not all $\mathrm{SAV}$ isolates from clinical samples can be cultured in fish cells in vitro, molecular techniques such as RT-PCR detection have been developed $(17,18,31)$. In PCR-based SAV diagnosis assays heart tissue samples are used rather than kidney ones. Real time RT-PCR protocols based on SYBR green (12) or TaqMan $(18,31)$ detection have been described and been shown to be specific and highly sensitive. For SAV detection, the OIE has approved a TaqMan realtime PCR technique based on the nsP1 gene developed by Hodneland and Endersen (18). Recently, Pinheiro et al. (28) have developed a multiplex RTPCR (mRT-PCR) assay for the single-assay simultaneous detection of four major rainbow trout viruses, namely viral haemorrhagic septicaemia virus (VHSV), infectious haematopoietic necrosis virus (IHNV), infectious pancreatic necrosis virus (IPNV), and SDV. The described method was able to efficiently detect the viral RNA in infected cell culture supernatants and in tissue samples, highlighting the presence of single infections as well as co-infections in rainbow trout samples. VHSV/SDV and IHNV/SDV co-infections were demonstrated for the first time in rainbow trout. The mRT-PCR method was proven to be an accurate and fast method to support traditional diagnostic techniques in the diagnosis of major viral diseases of rainbow trout.

Braceland et al. (7) have also identified and validated a novel selective precipitation reaction (SPR), establishing a procedure which can be used to monitor the health of farmed Atlantic salmon. The study has demonstrated that the assay is rapid, sensitive, and practical for daily operations. 
Table 2. Commercial vaccines against salmonid alphavirus

\begin{tabular}{|c|c|c|c|c|}
\hline Vaccine name & Company & Type & Delivery method & Target species \\
\hline PD & Pharmaq AS Norway & inactivated & injection & Atlantic salmon \\
\hline Norvax Compact PD & MSD Animal Health & inactivated & injection & Atlantic salmon \\
\hline AquaVac PD3 & MSD Animal Health & inactivated & injection & Atlantic salmon \\
\hline AquaVac PD7 & MSD Animal Health & inactivated & injection & Atlantic salmon \\
\hline
\end{tabular}

\section{Vaccination}

Based on the field observations showing that fish surviving SAV infections were resistant to reinfection, it has been suggested that vaccination may be applied for control of PD and SD. The results of the study by Graham et al. (16) support the expectations that a vaccine containing a single subtype strain can protect against PD caused by different strains of SAV, independent of their subtype grouping.

There are a few commercial vaccines against PD available. The PD vaccine produced by Pharmaq (Norway) and the monovalent Norvax Compact PD (NCPD) vaccine (MSD Animal Health, Norway) are based on an inactivated PD virus. Multivalent vaccines (the three-component AquaVac PD3 in Ireland and Scotland and the seven-component AquaVac PD7 in Norway) have been commercially available since 2015 and are also based on inactivated viruses (21) (Table 2).

In the case of the Norvax Compact PD vaccine a reduction in mortality of at least $50 \%$ is claimed in comparison of vaccinated fish against unvaccinated fish at the same farm (3). The Intervet Norbio vaccine showed reduction in histopathological damages $(3,21)$. It has been used in Norwegian aquaculture of salmon since 2007. A cohort study of the effect of vaccination on pancreas disease (3) showed the positive effects of the vaccination protocol against PD in Norwegian salmon farming. Vaccination has reduced the number of outbreaks and has decreased cumulative mortality and the number of discarded fish at slaughter as well as increased the growth rate compared to non-vaccinated fish.

On the other hand, the annual number of SAV3 outbreaks in Norway is still high, thus the prevention from PD provided by the Norvax Compact PD vaccine is questionable (9). Therefore, it was necessary to develop more effective alternatives, for example DNA vaccines that showed a high level of protection against rhabdoviruses in salmonids. In DNA vaccination it is not the antigen itself being administrated but the gene encoding the vaccine agent. Further antigen expression by cells in the vaccinated hosts triggers the host immune system. In a recent study (9) researchers compared the efficacy of two DNA vaccine constructs against SAV3 (pCSP and pE2) and a commercial vaccine based on inactivated SAV1 (Norvax Compact PD (NCPD)). The pCSP construct was a plasmid expressing the whole SAV3 structural polyprotein C-E3-E2-6K-E1, while plasmid pE2 encoded the SAV3 surface protein E2 alone. The study showed that vaccination with both $\mathrm{pCSP}$ and NCPD reduced the virus numbers in serum. The histopathological findings demonstrated that pCSP provided superior protection against SAV3 infections compared to NCPD and pE2. It was confirmed that the commercial NCPD vaccine increased protection against SAV3, but the results also revealed that it failed to protect fish against development of pathological lesions in the pancreas and heart. The authors claimed that it might partly explain the inability of NCPD to diminish outbreaks of $\mathrm{SAV}$ in Norwegian salmon farming. However, it was not clarified whether the inferior effect of NCPD on antibody production and protection compared to pCSP was due to its SAV1 derivation being second-best to pCSP's SAV3. However, E2 from SAV1 and this protein from SAV3 shows very high amino acid sequence identity (95\%).

It has also been demonstrated in experimental trials that both faeces and mucus are involved in the shedding of SAV from infected salmon (15). Andersen et al. (2) presented a modified VIRADEL (virusadsorption-elution) method to detect virus in water. The analyses of water samples collected during the SAV experimental challenge showed that viral shedding from SAV-infected fish coincides with viraemia. In a recent study, Skjold et al. (32) investigated the influence of PD vaccination on shedding of SAV to water. They performed an SAV challenge trial, comparing SAV shedding from PD-vaccinated fish to the same from unvaccinated fish. The results of the study demonstrated a significant decrease in shedding of SAV to water where vaccination against PD was instigated. This vaccine effect can play a major role in reducing the SAV infection pressure (a variable describing the potential for spread of local disease) within and between farms.

\section{Conclusion}

Salmonid alphavirus (SAV) infections have been known since the 1980s and have become economically significant salmonid diseases. Many studies have been performed to advance the knowledge of SAV and the disease itself, yet there are still a number of areas that 
require further research, such as transmission of the virus and possible risk related to the export of SAVinfected fish. Currently, fast and sensitive PCR-based techniques are in place for virus detection; however, they should not be used as the sole diagnostic indicator. A combination of histopathological examination, antibody detection, virus culture, and PCR technique should be used for diagnosis of SAV infections. As SAV infections are a large problem with economic importance, it is clear that aside from fast virus detection, prophylaxis against SAV is needed. Field observations showed that fish surviving SAV infections were resistant to reinfection, which made the case for development of vaccines with positive effects in controlling SAV diseases.

Conflict of Interests Statement: The authors declare that there is no conflict of interests regarding the publication of this article.

Financial Disclosure Statement: This work was financed by the Inland Fisheries Institute in Olsztyn.

\section{Animal Rights Statement: None required.}

\section{References}

1. Aldrin M., Huseby R.B., Jansen P.A.: Space-time modelling of the spread of pancreas disease (PD) within and between Norwegian marine salmonid farms. Prev Vet Med 2015, 121, 132-141.

2. Andersen L., Hodneland K., Nylund A.: No influence of oxygen levels on pathogenesis and virus shedding in Salmonid alphavirus (SAV)-challenged Atlantic salmon (Salmo salar L.). Virol J 2010, 7, 198.

3. Bang Jensen B., Kristoffersen A.B., Myr C., Brun E.: Cohort study of effect of vaccination on pancreas disease in Norwegian salmon aquaculture. Dis Aquat Organ 2012, 102, 23-31.

4. Bergmann S.M., Fichtner D., Riebe R., Castric J.: First isolation and identification of sleeping disease virus (SDV) in Germany. Bull Eur Assoc Fish Pathol 2008, 28, 148-156.

5. Borzym E., Maj-Paluch J., Stachnik M., Matras M., Reichert M.: First laboratory confirmation of salmonid alphavirus type 2 (SAV2) infection in Poland. Bull Vet Inst Pulawy 2014, 58, 341-345.

6. Boucher P., Baudin-Laurencin F.: Sleeping disease and pancreas disease: comparative histopathology and acquired crossprotection. J Fish Dis 1996, 19, 303-310.

7. Braceland M., Tinsley J., Cockerill D., Bickerdike R., McLoughlin M.F., Eckersall P.D.: Selective precipitation reaction: A novel diagnostic test for tissue pathology in Atlantic salmon, Salmo salar, infected with salmonid alphavirus (SAV3). J Fish Dis 2016, 40, 1077-1087.

8. Castric J., Baudin-Laurencin F., Brémont M., Jeffroy J., le Ven A., Bearzotti M.: Isolation of the virus responsible for sleeping disease in experimentally infected rainbow trout (Oncorhynchus mykiss). Bull Eur Assoc Fish Pathol 1997, 17, 27-30.

9. Chang C.J., Robertsen B., Gu J.: Protective effect and antibody response of DNA vaccine against salmonid alphavirus 3 (SAV3) in Atlantic salmon. J Fish Dis 2017, 40, 1775-1781.

10. Fringuelli E., Rowley H.M., Wilson J.C., Hunter R., Rodger H.D., Graham D.A.: Phylogenetic analyses and molecular epidemiology of European salmonid alphaviruses
(SAV) based on partial E2 and nsP3 gene nucleotide sequences. J Fish Dis 2008, 31, 811-823.

11. Graham D.A., Rowley H.M., Walker I.W., Weston J.H., Branson E.J., Todd D.: First isolation of sleeping disease virus from rainbow trout, Oncorhynchus mykiss (Walbaum), in the United Kingdom. J Fish Dis 2003, 26, 691-694.

12. Graham D.A., Taylor C., Rodgers D., Weston J.H., Khalili M., Ball N., Christie K.E., Todd D.: Development and evaluation of a one-step real-time reverse transcription polymerase chain reaction assay for the detection of salmonid alphaviruses in serum and tissues. Dis Aquat Organ 2006, 70, 47-54.

13. Graham D.A., Rowley H.M., Fringuelli E., Bovo G., Manfrin A., McLoughlin M.F., Zarza C., Khalili M., Todd D.: First laboratory confirmation of salmonid alphavirus infection in Italy and Spain. J Fish Dis 2007, 30, 569-572.

14. Graham D.A., Fringuelli E., Rowley H.M., Cockerill D., Cox D.I., Turnbull T., Rodger H., Morris D., McLoughlin M.F.: Geographical distribution of salmonid alphavirus subtypes in marine farmed Atlantic salmon, Salmo salar L., in Scotland and Ireland. J Fish Dis 2012, 35, 755-765.

15. Graham D.A., Brown A., Savage P., Frost P.: Detection of salmon pancreas disease virus in the faeces and mucus of atlantic salmon, Salmo salar L., by real-time RT-PCR and cell culture following experimental challenge. J Fish Dis 2012, 35, 949-951.

16. Graham D.A., Rowley H.R., Frost P.: Cross-neutralization studies with salmonid alphavirus subtype 1-6 strains: Results with sera from experimental studies and natural infections. J Fish Dis 2014, 37, 683-691.

17. Hodneland K., Bratland A., Christie K.E., Endresen C., Nylund A.: New subtype of salmonid alphavirus (SAV), Togaviridae, from Atlantic salmon Salmo salar and rainbow trout Oncorhynchus mykiss in Norway, Dis Aquat Organ 2005, $66,113-120$

18. Hodneland K., Endresen C.: Sensitive and specific detection of Salmonid alphavirus using real-time PCR (TaqMan $\left.{ }^{\circledR}\right)$. J Virol Methods 2006, 131, 184-192.

19. Infection with Salmonid Alphavirus. In: OIE Manual of Diagnostic Tests for Aquatic Animals, Paris, 2016.

20. Jansen M.D., Gjerset B., Modahl I., Bohlin J.: Molecular epidemiology of salmonid alphavirus (SAV) subtype 3 in Norway. Virol J 2010, 7, 188.

21. Jansen M.D., Bang Jensen B., McLoughlin M.F., Rodger H.D., Taksdal T., Sindre H., Graham D.A., Lillehaug A.: The epidemiology of pancreas disease in salmonid aquaculture: a summary of the current state of knowledge. J Fish Dis 2017, 40, 141-155.

22. Jewhurst V.A., Todd D., Rowley H.M., Walker I.W., Weston J.H., McLoughlin M.F., Graham D.A.: Detection and antigenic characterization of salmonid alphavirus isolates from sera obtained from farmed Atlantic salmon, Salmo salar L., and farmed rainbow trout, Oncorhynchus mykiss (Walbaum). J Fish Dis 2004, 27, 143-149.

23. Kongtorp R.T., Stene A., Andreassen P.A., Aspehaug V., Graham D.A., Lyngstad T.M., Olsen A.B., Olsen R.S, Sandberg M., Santi N., Wallace C., Breck O.: Lack of evidence for vertical transmission of SAV 3 using gametes of Atlantic salmon, Salmo salar L., exposed by natural and experimental routes. J Fish Dis 2010, 33, 879-888.

24. McCleary S., Giltrap M., Henshilwood K., Ruane N.M.: Detection of salmonid alphavirus RNA in Celtic and Irish Sea flatfish. Dis Aquat Organ 2014, 109, 1-7.

25. McLoughlin M.F., Nelson R.N., McCormick J.I., Rowley H.M., Bryson D.B.: Clinical and histopathological features of naturally occurring pancreas disease in farmed Atlantic salmon, Salmo salar L. J Fish Dis 2002, 25, 33-43.

26. McLoughlin M.F., Graham D.A.: Alphavirus infections in salmonids - a review. J Fish Dis 2007, 30, 511-531.

27. Nelson R.T., McLoughlin M.F., Rowley H.M., Platten M.A., McCormick J.I.: Isolation of a toga-like virus from farmed Atlantic salmon Salmo salar with pancreas disease. Dis Aquat Organ 1995, 22, 25-32. 
28. Pinheiro A.C.A.S., Volpe E., Principi D., Prosperi S., Ciulli S.: Development of a multiplex RT-PCR assay for simultaneous detection of the major viruses that affect rainbow trout (Oncorhynchus mykiss). Aquacult Int 2016, 24, 115-125.

29. Reid K.M., Patel S., Robinson A.J., Bu L., Jarungsriapisit J., Moore L.J., Salinas I.: Salmonid alphavirus infection causes skin dysbiosis in Atlantic salmon (Salmo salar L.) post-smolts. PLOS One 2017, 12, 1-17.

30. Schmidt-Posthaus H., Diserens N., Hjortaas M.J., Knüsel R., Hirschi R., Taksdal T.: First outbreak of sleeping disease in Switzerland: disease signs and virus characterization. Dis Aquat Organ 2014, 111, 165-171.

31. Shi W., Song A., Gao S., Wang Y., Tang L., Xu Y., Ren T., Li Y., Liu M.: Rapid and sensitive detection of salmonid alphavirus using TaqMan real-time PCR. Mol Cell Probes 2017, $34,13-20$.

32. Skjold P., Sommerset I., Frost P., Villoing S.: Vaccination against pancreas disease in Atlantic salmon, Salmo salar L., reduces shedding of salmonid alphavirus. Vet Res 2016, 47, $10-15$.

33. Stene A., Viljugrein H., Yndestad H., Tavornpanich S., Skjerve E.: Transmission dynamics of pancreas disease (PD) in a Norwegian fjord: Aspects of water transport, contact networks, and infection pressure among salmon farms. J Fish Dis 2014, 37, $123-13$.
34. Taksdal T., Olsen A.B., Bjerkås I., Hjortaas M.J., Dannevig B.H., Graham D.A., McLoughlin M.F.: Pancreas disease in farmed Atlantic salmon, Salmo salar L., and rainbow trout, Oncorhynchus mykiss (Walbaum), in Norway. J Fish Dis 2007, $30,545-558$

35. Taksdal T., Bang Jensen B., Böckerman I., McLoughlin M.F., Hjortaas M.J., Ramstad A., Sindre H.: Mortality and weight loss of Atlantic salmon, Salmo salar L., experimentally infected with salmonid alphavirus subtype 2 and subtype 3 isolates from Norway. J Fish Dis 2015, 38, 1047-1061.

36. Viljugrein H., Staalstrøm A., Molvær J., Urke H.A., Jansen P.A.: Integration of hydrodynamics into a statistical model on the spread of pancreas disease (PD) in salmon farming. Dis Aquat Organ 2009, 88, 35-44.

37. Villoing S., Béarzotti M., Chilmonczyk S., Castric J., Brémont M.: Rainbow trout sleeping disease virus is an atypical alphavirus. J Virol 2000, 74, 173-183.

38. Weston J.H., Villoing S., Brémont M., Castric J., Pfeffer M., Jewhurst V.A., McLoughlin M.F., Rødseth O., Christie K.E., Koumans J., Todd D.: Comparison of two aquatic alphaviruses, salmon pancreas disease virus, and sleeping disease virus, by using genome sequence analysis, monoclonal reactivity, and cross-infection. J Virol 2002, 76, 6155-6163. 